\title{
RELATORIO DA THESOURARIA
}

Exmo. Sr. Director,

Tenho a honra de apresentar a V. Excia., com a devida venia, o relatorio dos serviços da Thesouraria, a meu cargo, em 1936.

E' com justa satisfação que podemos affirmar, aqui, que os encargos todos affectos á Thesouraria foram rigorosamente desempenhados e attendidos, embora muitas vezes exigissem sacrificio e trabalho, além das horas de expediente. Esses encargos não são poucos. Vamos enumeral-os de maneira rapida, apenas para dar uma idéa dos affazeres que cabem ao Thesoureiro executar.

\section{SERVIÇOS A CARGO DA THESOURARIA}

\section{SERVIÇOS INTERNOS}

a) recebimentos

b) pagamentos (arrecadação de taxas, emolumentos, etc. (De despezas (Despezas diversas, acquições, etc.

(De pessoal (Folha de regencia de turma desdobrada.

(Folha do Collegio Universitario.

(Folha do serviço nocturno.

( " de contractados.

( " de effectivos.

c) fechamento da Caixa;

d) confecção do Boletim Diario para a Contadoria;

c) balanço no "stock" de Publicações;

f) escripturação dos livros da Thesouraria;

g) guarda dos comprovantes diarios de receita e despeza; (serviço do archivo da Thesouraria);

h) organização de prestação de contas de adeantamentos. 


\section{SERVIÇOS EXTERNOS}

Movimento bancario:

a) Retiradas e depositos em Bancos.

Movimento com o Thesouro do Estado:

b) Recebimento de adeantamentos e de Folhas de Pessoal - Devolução das Folhas e prestação de contas;

c) Recebimento de juros de Apolices;

d) procura de troco para pagamento de Folhas.

Comtudo, como dissémos em linhas atraz, todos esses multiplos affazeres foram executados, com zelo, rigor, e precisão. Diariamente foi fechado o movimento de Caixa e remettido á Contadoria o respectivo Boletim, acompanhado de seus comprovantes; a escripturação sempre mantida perfeitamente em dia, com clareza e exactidão. Releva notar, porém, que para attender áquelles serviços não possue a Thesouraria siquer um auxiliar, pois, no quadro do pessoal da Faculdade, não existe o cargo de fiel. E' uma falha, a nosso vêr, na organização existente, que se reflecte, algumas vezes, na bôa marcha dos serviços da Thesouraria, trazendo-lhes inconvenientes e demoras inevitaveis quando se accumulam. E' certo que nas occasiões extraordinarias, como occorre em principios do anno, destaca o Sr. Secretario um funccionario da Secretaria para nosso auxilio. Entretanto, não sendo o mesmo effectivo, e portanto sem pratica completa de todos os serviços da Thesouraria, perde bastante em efficiencia, o auxilio indispensavel e valioso que nos presta. Além disso, quando surge a necessidade de se attender a um serviço externo, não resta outro modo senão manter a Thesouraria fechada. São inconvenientes que, com a creação daquelle cargo, poderiam ser facilmente evitados, com proveito para o serviço.

O movimento registrado no exercicio de 1936 revelou-se bastante intenso. $O$ serviço de arrecadação foi dos mais trabalhosos e de vulto pelo grande numero de alumnos matriculados nos diversos Cursos da Faculdade. 
Renda ordinaria: As rendas ordinarias do Curso de Bacharelado arrecadadas em 1936, pela Thesouraria, foram as seguintes:

$$
\begin{aligned}
& \text { 1.0 anno } \quad \ldots \ldots \ldots 60 \% \\
& \text { 2.0 anno } \quad \ldots \ldots \ldots .661: 720 \$ 000 \\
& 3 . .^{\circ} \text { anno } \ldots \quad \ldots \ldots \ldots .75: 225 \$ 000 \\
& 4 .^{\circ} \text { anno } \ldots \quad \ldots . .50: 840 \$ 000 \\
& \text { 5.0 anno } \quad \ldots \ldots .70: 170 \$ 000 \quad 318: 615 \$ 000
\end{aligned}
$$

Folhas de pagamento: A Thesouraria effectuou mensalmente o pagamento das seguintes Folhas: "Folha do Pessoal Effectivo - (Folha a cargo do Thesouro) - Folha do pessoal que prestou serviços ao Collegio Universitario, Folha de serviços nocturnos, Folha de serviços custeados pelas rendas internas, Folha de Contractados, Folha de regencia de Turmas Desdobradas.

Movimento geral de Receita e Despeza (recebimentos e pagamentos): Iniciado o anno de 1936 com o saldo em Caixa de rs. 49:003 $\$ 300$ passaram a debito de Caixa, (Recebimentos) até 31 de dezembro rs. 2.559:209\$400, e a credito (Pagamentos sahidos) rs. 2.566:381 $\$ 100$, encerrando-se o anno com rs. 41:831 $\$ 600$ de saldo em Caixa. A' vista destes algarismos fica bem evidenciado o movimento effectuado pela Thesouraria em 1936.

Tomada de Contas: Nomeado por V. Excia. o Sr. Perito Julio Pinheiro de Carvalho para fazer a revisão integral da escripturação da Thesouraria e o seu confronto com os comprovantes, no periodo de 24 de abril de 1934 a 15 de agosto de 1936, collocamos á sua disposição todos os livros e documentos da Thesouraria relativos áquelle periodo. Concluindo o seu minucioso trabalho, o perito encarregado por V Excia., apresentou o relatorio do seu serviço, publicado na Revista da Faculdade, Volume XXXII, fasciculo II pelo qual se verifica ter encontrado os serviços a cargo do Thesoureiro em perfeita ordem, com a respectiva escripturação em dia, reflectindo a expressão da verdade. 
Prestação de contas ao Thesouro do Estado: Foram apresentadas devidamente ao Thesouro do Estado as contas relativas aos adeantamentos mensaes, para pagamento de Serviço Nocturno e para pagamento da Folha do Pessoal Effectivo.

São estes os principaes factos que me cumpre relatar. São Paulo, 31 de março de 1937.

Heitor de Souza Lima

Thesoureiro 